\title{
Labelling in Mediterranean agroforestry landscapes: a Delphi study on relevant sustainability indicators
}

\author{
Lukas Flinzberger $^{1} \cdot$ Yves Zinngrebe $^{1} \cdot$ Tobias Plieninger $^{1,2}$
}

Received: 29 October 2019 / Accepted: 16 March 2020 / Published online: 3 April 2020

(c) The Author(s) 2020

\begin{abstract}
In the face of unsustainable land-use changes including intensified agricultural production and land abandonment, agroforestry systems have the potential to support a diversity of social and ecological functions in agricultural landscapes. Mediterranean agroforestry landscapes have been conserved through traditional practices, and new concepts are necessary to assure the viability of these practices. Labels bear the opportunity to indicate sustainable management along the supply chain and, at the same time, generate higher incomes for sustainably producing farms. We have used an expert-based Delphi survey with three iterative surveys to analyse (1) the relevance of different sustainability aspects in agroforestry systems, (2) the suitability of derived indicators for labelling, and (3) the specific potentials and barriers for labelling agroforestry production or ecological UN Sustainable Development Goal (SDG) — are considered relevant for agroforestry systems. Translating these goals into suitable indicators is the more challenging step, revealing the lack of appropriate data, the complexity of sustainability challenges, and a low willingness for producers to adapt their practices as key limiting factors. The assessment of the labelling schemes indicated coherent responses despite the diverse backgrounds of participants. Alongside eco-labels and social labels, Geographic Indications were suggested as the most suitable options for the agroforestry context, although these have not been invented for reflecting sustainability in the first place. Although experts are highly aware of social-cultural values of agroforestry systems, they see little potential to use those social-cultural aspects for labelling agroforestry products. Initial costs and missing consumer awareness for agroforestry are major reasons for not joining labelling schemes. We discuss the possibility of an agroforestry label and why elements of Geographic Indication labels may fit well for this purpose.
\end{abstract}

Keywords Certification · Sustainable Development Goals (SDGs) · Geographic Indications · Multifunctional agriculture · Landscape management $\cdot$ Ecosystem services

\section{Introduction}

Handled by José Muñoz-Rojas, University of Évora, Portugal.

Electronic supplementary material The online version of this article (https://doi.org/10.1007/s11625-020-00800-2) contains supplementary material, which is available to authorized users.

Lukas Flinzberger

lukas.flinzberger@uni-goettingen.de

1 Department of Agricultural Economics and Rural Development, University of Göttingen, Platz der Göttinger Sieben 5, 37073 Göttingen, Germany

2 Faculty of Organic Agricultural Sciences, University of Kassel, Steinstr. 19, 37213 Witzenhausen, Germany
Agricultural landscapes face various sustainability challenges related to structural transformations, associated with for instance intensification, scale enlargement, and land abandonment. Intensification can have consequences such as reduced soil conservation (Lorenz and Lal 2014), higher greenhouse gas emissions (Aertsens et al. 2013), and higher water demands (Camilli et al. 2018). Abandonment, on the other side, leads to reduced production capacities in rural landscapes (Hertel 2015), losses of cultural values of landscapes (Costa et al. 2014, 2011), and reduced agrobiodiversity (Mosquera-Losada et al. 2018; Bugalho et al. 2011). To guide society towards sustainability, the United Nations have released the Sustainable Development Goals (SDGs) that emphasise the indivisibility of biological conservation, 
health, well-being, economic innovation, and other goals. While these goals outline an ambitious pathway to a more sustainable society, currently prevalent forms of agriculture and agricultural policy are in conflict with a number of SDGs (Mann et al. 2018; Kanter et al. 2018). For example, rules of the EU Common Agriculture Policy do not provide an effective contribution to the SDGs (Pe'er et al. 2019). It performs especially weak regarding SDGs such as "clean water" or "life on land" (Pe'er et al. 2017). Given that climate change impacts such as water scarcity or wildfires will be of particular severity in the Mediterranean region, alternative approaches are needed to preserve social-ecological functions embedded in agricultural landscapes (Malek et al. 2018). Thus, reversing the current trajectory of non-sustainable intensification and promoting more resilient agricultural practices are long overdue.

\section{Sustainability of agroforestry systems}

One strategy to facilitate a transition of agricultural systems towards better coverage of the SDGs is agroforestry-a landuse practice that has been reported to provide synergies between different dimensions of sustainability and between multiple ecosystem services (Campos et al. 2019; MosqueraLosada et al. 2018; Jose 2009). Previous studies showed that agroforestry systems often support a high biodiversity (Torralba et al. 2016; Mosquera-Losada et al. 2012), are effective for tackling climate change (Mosquera-Losada et al. 2018; Montagnini 2017; Lin 2011), and can transmit high values of cultural identification and well-being (Moreno et al. 2018; Plieninger and Huntsinger 2018). One global hotspot of agroforestry is the Mediterranean region (Gauquelin et al. 2018, den Herder et al. 2017, Malek and Verburg 2017). Mediterranean agroforestry landscapes were formed through a long tradition of human maintenance, partly since preRoman times (Mosquera-Losada et al. 2012; Aronson et al. 2009). By that, they form cultural landscapes that are part of a rural cultural heritage (Torralba et al. 2018b) and have intrinsic aesthetic values (Torralba et al. 2018a). They are often perceived as natural, although, in fact, they are based on well-balanced practices of extensive management (Wolpert et al. 2020; Lovrić et al. 2018; Huntsinger and Oviedo 2014). While scientific literature has highlighted the various ecosystem services from agroforestry systems, current agricultural policies do not show awareness for the societal value of agroforestry (Santiago-Freijanes et al. 2018a, b; Pisanelli et al. 2014). Thus, subsidies and market changes have decreased the economic profitability of agroforestry, led to land-use polarisation, and endangered the socialecological integrity of Mediterranean agroforestry systems (Escribano et al. 2018; Hartel and Plieninger 2014).

\section{Potentials and barriers of labelling in multifunctional landscapes}

Agroforestry needs viable economic approaches and profitability to withstand current trajectories of land abandonment and intensification while maintaining, developing, and revitalising sustainable land management practices around the traditional agroforestry. The potential of labelled agroforestry systems to strengthen the SDG agenda has not been explored in detail yet. While the general benefits of labelling have been theoretically described and demonstrated in various case studies (OECD 2016; Millard 2011), there are no specific labels for products from agroforestry. Typical problems for product labelling in agroforestry are initial and ongoing costs for implementation and marketing (Lovrić et al. 2018; Tscharntke et al. 2015), a lack of distribution channels and adequate market infrastructure (Mann and Plieninger 2017), a lack of consumers' awareness, missing price premiums (Horrillo et al. 2016), and the technical issues of complying with and monitoring of label standards (Mann et al. 2018). Furthermore, it is challenging to define applicable (producer side) and understandable (consumer side) indicators for monitoring and marketing that clearly relate to agroforestry features and the SDGs in a broad sense.

While a number of labels and certificates focus on single aspects of land use (e.g., organic production practices, animal welfare standards, and GMO-free food), labels referring to multifunctional land management practices such as agroforestry are scant. So far, only a few researchers have addressed agroforestry-specific labelling (Escribano et al. 2018). Common forestry labels like FSC or PEFC have recently started to include specific standards for some forms of agroforestry (in particular, for cork production), but do not use the term "agroforestry" in their labels (Masiero et al. 2011; Dias et al. 2015). Food labels so far do not explicitly highlight agroforestry, although many food products are strongly linked with agroforestry systems, for instance, orchard meadow fruits, olive oil, or Iberian ham (Herzog 1998; Egea and Pérez y Pérez 2016; Mann and Plieninger 2017). Agroforestry systems often represent biodiversity-rich as well as cultural valuable landscapes and are based on sustainable management practices (Elevitch et al. 2018). These examples demonstrate the strong but yet unused potential to include agroforestry systems into sustainability labels.

\section{Research questions}

In this study, the potential of sustainability labelling for supporting Mediterranean agroforestry systems is analysed 
by asking the following key questions: (1) Which aspects of sustainability are considered relevant for agroforestry production systems and which indicators can represent the respective aspects? (2) Which label types can indicate the relevant sustainability aspects from producers to consumers in a comprehensive and understandable way? (3) Which potentials do agroforestry-related labels have and which barriers for implementation or communication do they face?

The next section presents the intermediate steps of the expert-based Delphi methodology adjusted to the analysis of Mediterranean agroforestry systems. Subsequently, results are displayed in response to the three research questions leading to a synthesised assessment of relevant sustainability indicators. This is followed by a discussion of the possibilities of agroforestry-specific indicators and the potential role of Geographic Indications in agroforestry labelling, leading to the final conclusions.

\section{Method}

\section{The Delphi approach}

We carried out a Delphi survey in the form of a three-round online survey among agroforestry experts. By facilitating a consensus process among participants, the Delphi technique helped us to identify common opinions and iteratively letting the participants assess those findings. We constructed our Delphi questionnaire as a mix of the 'decision' and 'scenario' Delphi according to the typology by Mukherjee et al. (2015). With the multi-round approach, we were able to feed intermediate results back into the survey in an anonymized way. A similar Delphi method has been used by Escribano et al. (2018) for finding sustainability indicators for dehesa agroforestry farms. While the latter study focused more on a consensus approach by repeating the same questions, we carried out a scoping-like Delphi survey where the different rounds built upon each other, leading to a collective opinion on the topic (Horrillo et al. 2016). Anonymous feedback enabled us to share information with the participants without risking any self-censoring due to societal expectations.

\section{Sampling}

Following Hasson et al. (2000), we conducted a purposive sampling in which we "hand-picked" and invited experts with professional and/or academic backgrounds in Mediterranean agroforestry systems. In the beginning, we addressed potential participants through agroforestry research and practice networks (EURAF, AGFORWARD, AFINET, and EIP AGRI) and asked them to suggest further colleagues or collaborators. In this way, we finally invited 48 selected experts to the first survey round. The list of participants consisted of scientists, institutional and private researchers, and scientifically trained practice partners from the fields of agroforestry and labelling. Finally, 23 respondents answered the first round of our survey, 18 respondents completed the second round, and 13 respondents answered the questionnaire in the final round. Experience from other Delphi studies shows that this method is useful for eliciting judgements from expert respondents even when achieving only small sample sizes. Our respondent numbers were similar to the median value of 20 respondents (according to the review of 49 Delphi studies by Mukherjee et al. (2018).

Within the 23 respondents that completed the first round, we identified three groups: 10 senior academics (age $40+$ and/or $20+$ years of experience), four junior academics (younger and less experienced researchers affiliated with universities), and nine non-academic respondents (currently not working at a university).

\section{Survey design and implementation}

In our three-round survey, we included ranking, rating, and free listing tasks, as well as questions about potentials, barriers, and predictions for future development. Figure 1 shows a flowchart of the main ranking and rating tasks in all three survey rounds. Throughout the survey, we followed three lines of interest (see three columns within the flowchart) that were coherent with our research questions: (1) aspects and indicators; (2) labelling options in agroforestry systems, and (3) potentials and barriers for labelling in agroforestry.

We gave feedback in between the different survey rounds in the form of a brief descriptive summary of the previous round. Therefore, we provided the rankings and Likert ratings of the sustainability aspects and the labelling options. Except for one question, all Likert scales ranged from one to five (zero for no answer), and for the ranking tasks, we assigned the highest scores to the top-ranked items and vice versa (e.g., for the 12-item ranking, the top item received 12 points, the lowest item received 1 point, items not ranked received no points). Before inviting the participants to the surveys, we pre-tested the survey structure and the clarity of the questions with colleagues experienced in agroforestry, sustainability, or labelling.

To have a starting point for finding a consensus on relevant sustainability indicators for agroforestry systems, we scanned relevant literature and consulted the SDGs. Additionally, from the literature, we extracted a list of aspects that reflect the concept sustainability in general or for agroforestry in particular (Escribano et al. 2018; Pollastrini et al. 2018; Nair and Toth 2016). To cover sustainability in all its facets, we derived one agroforestryspecific sustainability aspect from each of the 17 SDGs. During the first survey round, the participants ranked 


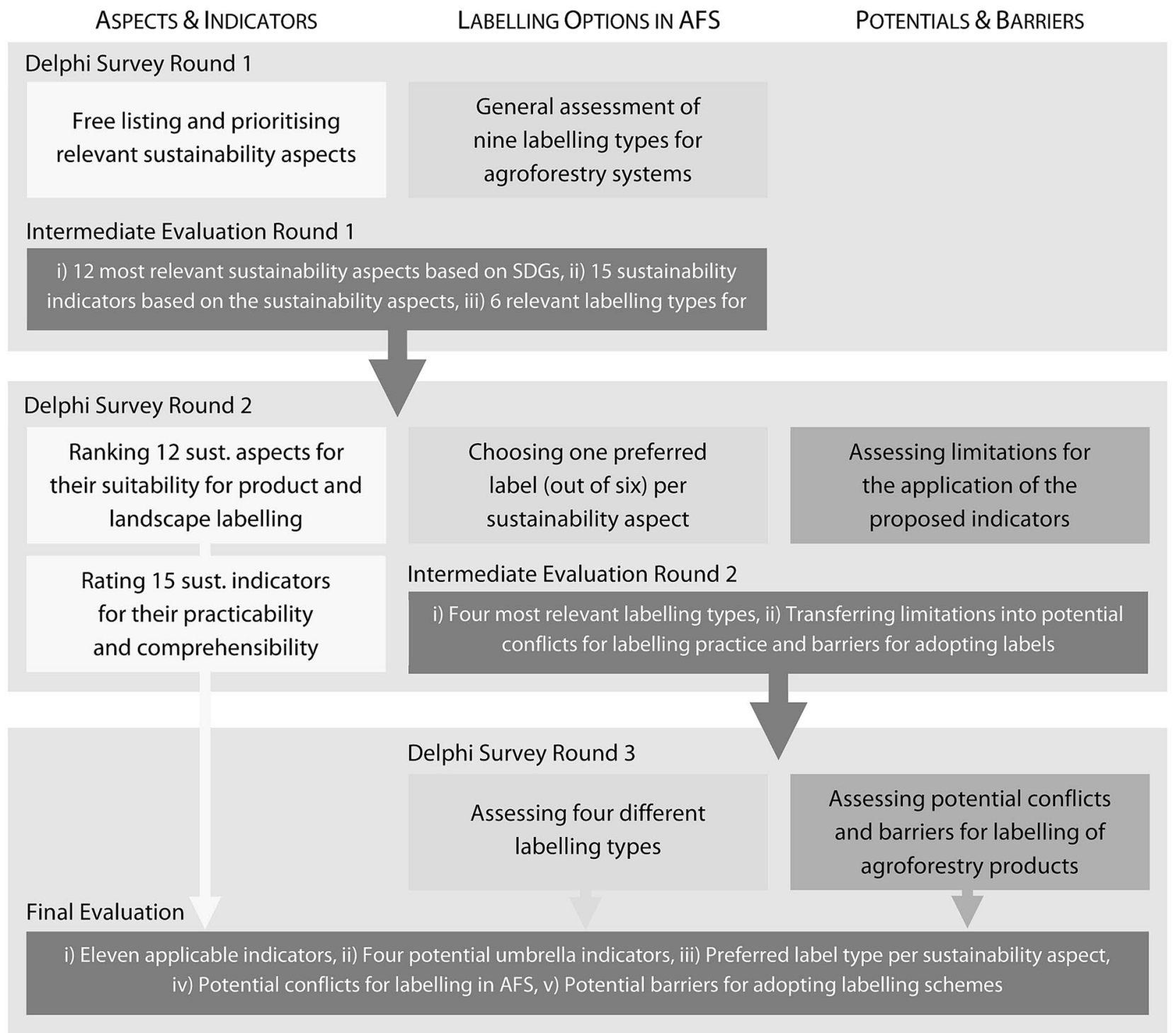

Fig. 1 Flowchart presenting the central tasks that the survey participants carried out and the intermediate evaluation steps performed to create an input for the subsequent rounds (AFS = agroforestry systems)

those 17 sustainability aspects three times for (1) their ability to represent sustainable management, (2) for their applicability for monitoring, and (3) for their potential to be communicated to consumers. The respondents added more aspects in a free listing task. Furthermore, they also ranked a list of nine given labelling or certification types three times for their suitability regarding sustainable landscape management, technical implementation and communicating sustainability. Besides this, we asked the participants for demographic data and about agroforestry systems and products which they are familiar with and for a general assessment of the current state of sustainability in agroforestry.
During the first intermediate step, we condensed a 17-item list of SDG-based sustainability aspects into a 12-item list of relevant aspects. For processing the free listing answers of sustainability aspects we aggregated 18 categories of sustainability aspects from the free listing and chose the nine most frequently mentioned categories. The ranking task of the SDG-based aspects also yielded nine high-ranked aspects. Five of the nine free listing aspects were similar to the SDG-based aspects. Thus, we obtained a list of the 12 most relevant sustainability aspects (Table 1 ). SDG 2 (no poverty), SDG 5 (gender equality), SDG 7 (clean energy), SDG 11 (sustainable cities) and SDG 14 (life below water) dropped out due to the low ranking of the suitability 
Table 1 Twelve relevant sustainability aspects were defined from free listing and ranking in Delphi Round 1 (left column). Subsequently, 15 corresponding sustainability indicators (right column) were proposed

\begin{tabular}{|c|c|}
\hline Relevant sustainability aspects & Corresponding indicators \\
\hline Income and social coherence from agroforestry & Salaries paid to farmworkers compared to national median income [\%] \\
\hline Improved quality of rural living conditions & Paid vacation [days/year] \\
\hline Efficient use of natural resources (including water and soil) & $\begin{array}{l}\text { Availability of an environmental management plan (erosion, pollution, } \\
\text { resource depletion, etc.) [yes/no] }\end{array}$ \\
\hline Diversification, innovation, and resilience in agroforestry systems & Share of revenues from direct sales and local markets [\%] \\
\hline Structural and functional biodiversity & $\begin{array}{l}\text { Share of area set aside for natural vegetation areas [\%] } \\
\text { Abundance of registered bird species [number of birds] }\end{array}$ \\
\hline Training and education on agroforestry & $\begin{array}{l}\text { Training days for workers on sustainability practices, techniques, and } \\
\text { tools [days/year] }\end{array}$ \\
\hline Climate-smart agriculture (mitigation and adaption) & $\begin{array}{l}\text { Trees per area [no of trees/ha] } \\
\text { Renewable energy consumption [\%] }\end{array}$ \\
\hline Integrated pest and fertiliser management & No chemical fertilisers and pesticides [yes/no] \\
\hline Stakeholder/community participation and empowerment & Access to knowledge networks for farmers [yes/no] \\
\hline Maintenance of cultural heritage and social networks & $\begin{array}{l}\text { Use of cultural landscape characteristics or local traditions for market- } \\
\text { ing [yes/no] }\end{array}$ \\
\hline $\begin{array}{l}\text { Availability of financing options (e.g., farm income, loans, and subsi- } \\
\text { dies) }\end{array}$ & $\begin{array}{l}\text { Share of revenues that stays with producer [\%] } \\
\text { Share of revenues, compensating for ecosystem services provision [\%] }\end{array}$ \\
\hline Support for sustainable production infrastructure & Involved in local/regional planning processes [yes/no] \\
\hline
\end{tabular}

in the context of agroforestry. From the ranking of the labels and certifications, we extracted six relevant items.

Based on the 12 sustainability aspects, we defined 15 sustainability indicators for agroforestry contexts, which we then introduced during the second round (Table 1). As main criteria for choosing an indicator, we looked for (1) easy determination of a value/answer, (2) high level of representation of agroforestry landscape issues, and (3) credibility of the indicator (van Oudenhoven et al. 2018). For three sustainability aspects, we found two equally sensible but technically different indicators that we included both. Thus, in Round 2, we presented 15 indicators for 12 sustainability aspects to the respondents.

During the second survey round, the participants again ranked the 12 sustainability aspects twice. Once, for how well the aspect can be supported by labelling an agroforestry product and second, for how well it could be supported by labelling the landscape management. Furthermore, they chose their preferred label type for each of the 12 sustainability aspects and gave Likert ratings to the 15 sustainability indicators for practical applicability and consumers' understanding. Also in Round 2, the respondents selected limiting factors for applying the indicators, and with this, we closed the consensus measure on sustainability aspects and indicators (left column of the flowchart, Fig. 1).

Round 3 was based on the consensus for the three most relevant labelling types from a choice task in Round 2 where the respondents stated their preferred label for each sustainability aspect. As we added a hypothetical fourth option of an 'agroforestry label', the respondents had to assess four different labelling options regarding four different qualities: (1) introducing and guaranteeing standards; (2) having tradeoffs or conflicts; (3) producers' identification with the label; and (4) consumers' understanding of the label. Finally, in our last round of the Delphi survey, we asked the participants to rate four potential conflicts that could occur around labelling agroforestry products and we asked them for the most likely barriers that could hinder the adoption of labelling standards.

\section{Results}

\section{General information}

The participants stated to be familiar with various types of agroforestry and different agroforestry products. Table 2 shows the more and less commonly known agroforestry types and products among the respondents.

\section{Sustainability aspects and indicators}

During Round 2, the 12 relevant sustainability aspects were ranked again twice for their suitability for (1) labelling agroforestry products and (2) labelling agroforestry landscape management (Table 3). The efficient use of resources was ranked most suitable in both cases and also climate-smart agriculture, biodiversity, diversification, and rural livelihood were ranked relatively high. The two rankings yielded mostly congruent results. Only for income and sustainable 
Table 2 Number of respondents that stated to be familiar with particular agroforestry systems and products

\begin{tabular}{lrrlrr}
\hline Agroforestry systems & $n$ & $\%$ & Agroforestry products & $n$ & $\%$ \\
\hline Silvopastoralism & 14 & 61 & Tree crops & 18 & 78 \\
Silvoarable lands & 9 & 39 & Food crops & 14 & 61 \\
Multi-purpose hedgerows & 5 & 22 & Timber & 12 & 52 \\
Short-rotation plantation & 4 & 17 & Services (e.g., tourism and recreation) & 12 & 52 \\
Alley cropping & 8 & 35 & Fodder crops & 10 & 43 \\
Windbreaks & 3 & 13 & Food products from animals & 8 & 35 \\
Mixed farming systems & 9 & 39 & Wooden or plant-based fuel & 8 & 35 \\
& & & Cork & 6 & 26 \\
& & & Non-food products from animals & 2 & 9 \\
& & & Other & 2 & 9 \\
\hline
\end{tabular}

fertiliser management experts ranked the suitability for product labelling much higher than for landscape labelling. Biodiversity was ranked more suitable for landscape labelling. Furthermore, the participants rated 15 sustainability indicators for their suitability regarding practical applicability and consumers' understanding. In Table 3, we present three colour-coded classes of indicators' suitability, which are green for usable indicators, yellow for usable indicators with minor restrictions, and red for indicators that based on experts' assessment cannot be recommended to use. Thus, 11 out of 15 indicators are recommendable to use, and in our discussion section, we explain why we propose the four green-rated indicators as "umbrella indicators". In addition to the colour-coding, the text within this field briefly describes the restrictions. Type, form, and duration of land ownership were suggested as additional suitable indicators in the free text section of Round 3, referring to contract duration and whether compensation for investments during the contract time exists.

\section{Labelling in agroforestry_potentials and barriers}

When choosing their preferred label type for improving each sustainability aspect (Table 4), we found that for environmental aspects, the experts dominantly chose eco-labels (chosen for five aspects), and regarding the social and economic aspects, they mainly opted for social labels (chosen for four aspects). For two aspects, related to cultural heritage and access to finance, the respondents chose Geographic Indication labels as the optimal representation. For the sustainability aspect representing SGD 16, the participants suggested process and production audits. The fact that ecolabels were chosen most often is in line with the high rating for their comprehensiveness (4.11 Likert points). In addition, eco-labels were chosen for the sustainability aspects with the highest relative rankings. This correlation of relative ranking of the aspect and rating for comprehensiveness appears less clearly for 'social and fair trade labels' which received 3.00 points for comprehensiveness and were assigned to the medium ranked aspects, while 'labels for geographic origin' (Geographic Indications) which were suggested for the lowest-ranked aspects got 3.12 points for comprehensiveness. Furthermore, we found no patterns regarding the choice of labels when looking at the rating for applicability or understanding of the respective sustainability indicator. Similarly, the different factors that limit the indicators' application appear not to be related to certain label types in particular.

Four selected labels were rated according to four different questions during Round 3 (Fig. 2). Three of them were the top-chosen labels from Round 2. The fourth one, a hypothetical agroforestry label, was introduced with the following explanation: "This describes a potential label or certificate that comprises the complexity of sustainability (maybe based on the SDGs) and promotes the diversity and resilience of agroforestry systems, aiming at the willingness to consume from those 'healthy' systems". In all four questions, Geographic Indications received the best rating and 'controlled eco-labels' the second-best. While the hypothetical agroforestry label was rated as the third-best option regarding 'potential conflicts or trade-offs' and 'producers' identification' with the label, it came last for 'easiness to introduce and guarantee the standard' and for 'consumers' understanding'. The 'social and fair trade labels' received the lowest rating regarding the 'potential conflicts or trade-offs' and for the 'producers' identification'.

In our second survey round, we asked for the most limiting factors for the implementation of each indicator and counted the two most frequently mentioned ones as relevant. For $87 \%$ of all indicators, experts mentioned a lack of valid data as the main limiting factor, followed by the lack of willingness of producers (for $60 \%$ of all indicators), a lack of expertise for monitoring (40\%), as well as problematic policies or land tenure $(27 \%)$.

As a closing question for Round 2, we asked for the relevance of connected concepts regarding the management or assessments of agroforestry systems. We found all four concepts rated as relevant, with multifunctionality being most important (4.67 Likert points) and resilience (4.44) as well 
Table 3 Summary of the key results on the relevant sustainability aspects (based on SDGs) with their rankings for their suitability with regard to product labelling or landscape labelling. Furthermore, it shows the ratings for each sustainability indicator and a recommendation for potential application. The indicator ratings are colour coded as follows: green rating above median value, yellow rating below median but above 10th percentile, red rating below 10th percentile. Indicator classification: green usable indicators, yellow usable with minor restrictions, red not recommended to use. $(\mathrm{ES}=$ ecosystem services)

\begin{tabular}{|c|c|c|c|c|c|c|c|}
\hline SDG & $\begin{array}{l}\text { Sustainability } \\
\text { aspect for AFS }\end{array}$ & $\begin{array}{c}\text { Aspects' } \\
\text { suitability for } \\
\text { product labelling }\end{array}$ & $\begin{array}{l}\text { Aspects' } \\
\text { suitability for } \\
\text { landscape } \\
\text { labelling }\end{array}$ & $\begin{array}{c}\text { Sustainability } \\
\text { indicator for AFS }\end{array}$ & $\begin{array}{l}\text { Indicators rated for } \\
\text { applicability }\end{array}$ & $\begin{array}{l}\text { Indicators rated for } \\
\text { comprehensibility }\end{array}$ & $\begin{array}{c}\text { Classification of } \\
\text { indicators' suitability }\end{array}$ \\
\hline 1 hovers & $\begin{array}{l}\text { Income \& social } \\
\text { coherence from } \\
\text { agroforestry }\end{array}$ & 4 & 9 & $\begin{array}{l}\text { Salaries paid to } \\
\text { farmworkers }\end{array}$ & 4.00 & 4.11 & $\begin{array}{l}\text { Applicable and } \\
\text { understandable }\end{array}$ \\
\hline 3 CODD HEALH & $\begin{array}{l}\text { Improved quality of } \\
\text { rural living conditions }\end{array}$ & 5 & 4 & Paid vacation days & 3.18 & 3.65 & $\begin{array}{l}\text { Understandable but } \\
\text { problematic } \\
\text { applicability }\end{array}$ \\
\hline 4 果 & $\begin{array}{l}\text { Education \& } \\
\text { knowledge on } \\
\text { sustainable } \\
\text { agroforestry }\end{array}$ & 9 & 6 & $\begin{array}{l}\text { Training-days on } \\
\text { sustainability } \\
\text { practices }\end{array}$ & 3.67 & 2.88 & $\begin{array}{l}\text { Applicable but } \\
\text { problematic } \\
\text { understanding }\end{array}$ \\
\hline 6 & $\begin{array}{l}\text { Sustainable pest \& } \\
\text { fertilizer } \\
\text { management }\end{array}$ & 6 & 12 & $\begin{array}{l}\text { No chemical } \\
\text { fertilizers and } \\
\text { pesticides }\end{array}$ & 4.18 & 4.56 & $\begin{array}{l}\text { Applicable and } \\
\text { understandable }\end{array}$ \\
\hline 8 & $\begin{array}{l}\text { Diversification \& } \\
\text { innovation for } \\
\text { competitive } \\
\text { agroforestry farms }\end{array}$ & 2 & 5 & $\begin{array}{l}\text { Revenues from } \\
\text { direct sales }\end{array}$ & 3.06 & 3.00 & Critical applicability \\
\hline 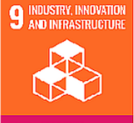 & $\begin{array}{l}\text { Cultural heritage \& } \\
\text { social networks }\end{array}$ & 12 & 11 & $\begin{array}{l}\text { Use of cultural } \\
\text { landscape } \\
\text { characteristics for } \\
\text { marketing }\end{array}$ & 3.50 & 3.50 & $\begin{array}{l}\text { Applicable and } \\
\text { understandable }\end{array}$ \\
\hline 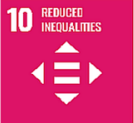 & Access to financing & 10 & 9 & $\begin{array}{l}\text { Final revenues for } \\
\text { producer }\end{array}$ & 3.25 & 3.41 & $\begin{array}{l}\text { Understandable but } \\
\text { problematic } \\
\text { applicability }\end{array}$ \\
\hline 10 ReDugen & options & 10 & 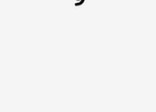 & $\begin{array}{l}\text { Revenues, } \\
\text { compensating for ES } \\
\text { provision }\end{array}$ & 3.56 & 3.00 & $\begin{array}{l}\text { Applicable but } \\
\text { problematic } \\
\text { understanding }\end{array}$ \\
\hline 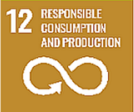 & $\begin{array}{l}\text { Efficient use of } \\
\text { natural resources }\end{array}$ & 1 & 1 & $\begin{array}{l}\text { Availability of } \\
\text { environmental } \\
\text { management plan }\end{array}$ & 4.22 & 3.35 & $\begin{array}{l}\text { Applicable but } \\
\text { problematic } \\
\text { understanding }\end{array}$ \\
\hline 13 allatil & $\begin{array}{l}\text { Climate-smart } \\
\text { agriculture }\end{array}$ & 3 & 3 & $\begin{array}{l}\text { Number of trees per } \\
\text { area } \\
\text { Renewable energy } \\
\text { consumption }\end{array}$ & 3.35 & 3.56 & $\begin{array}{l}\begin{array}{l}\text { Understandable but } \\
\text { problematic } \\
\text { applicability }\end{array} \\
\text { Understandable but } \\
\text { problematic } \\
\text { applicability }\end{array}$ \\
\hline & $\begin{array}{l}\text { Structural and } \\
\text { functional }\end{array}$ & 7 & 2 & $\begin{array}{l}\text { Area set aside for } \\
\text { natural vegetation }\end{array}$ & 4.00 & 3.56 & $\begin{array}{l}\text { Applicable and } \\
\text { understandable }\end{array}$ \\
\hline & biodiversity & & & $\begin{array}{l}\text { Registered bird } \\
\text { species }\end{array}$ & 2.81 & 3.56 & Critical applicability \\
\hline 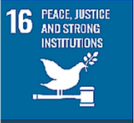 & $\begin{array}{l}\text { Support for } \\
\text { sustainable } \\
\text { production } \\
\text { infrastructure }\end{array}$ & 11 & 7 & $\begin{array}{l}\text { Involvement in } \\
\text { landscape planning } \\
\text { processes }\end{array}$ & 3.50 & 2.72 & Critical understanding \\
\hline 17 PaRTERBHIFS & $\begin{array}{l}\text { Community } \\
\text { participation \& } \\
\text { stakeholder } \\
\text { empowerment }\end{array}$ & 8 & 8 & $\begin{array}{l}\text { Access to } \\
\text { knowledge } \\
\text { networks }\end{array}$ & 3.83 & 2.78 & Critical understanding \\
\hline
\end{tabular}


Table 4 Labelling types that were suggested most frequently as suitable to improve the respective sustainability aspect. Column two shows the label type that experts suggested. Column three shows the frequency $(n)$ of suggestions among all 18 respondents of Delphi Round 2

Relevant sustainability aspects Label type suggested by experts

Income and social coherence from agroforestry

Social and fair trade labels

Improved quality of rural living conditions

Social and fair trade labels

Education and knowledge on sustainable agroforestry

Social and fair trade labels

Sustainable pest and fertiliser management

Eco-labels

Diversification and innovation for competitive agroforestry farms

Eco-labels

Cultural heritage and social networks

Geographic Indication labels $\quad 8$

Access to financing options

Geographic Indication labels

Efficient use of natural resources

Eco-labels

Climate-smart agriculture

Eco-labels

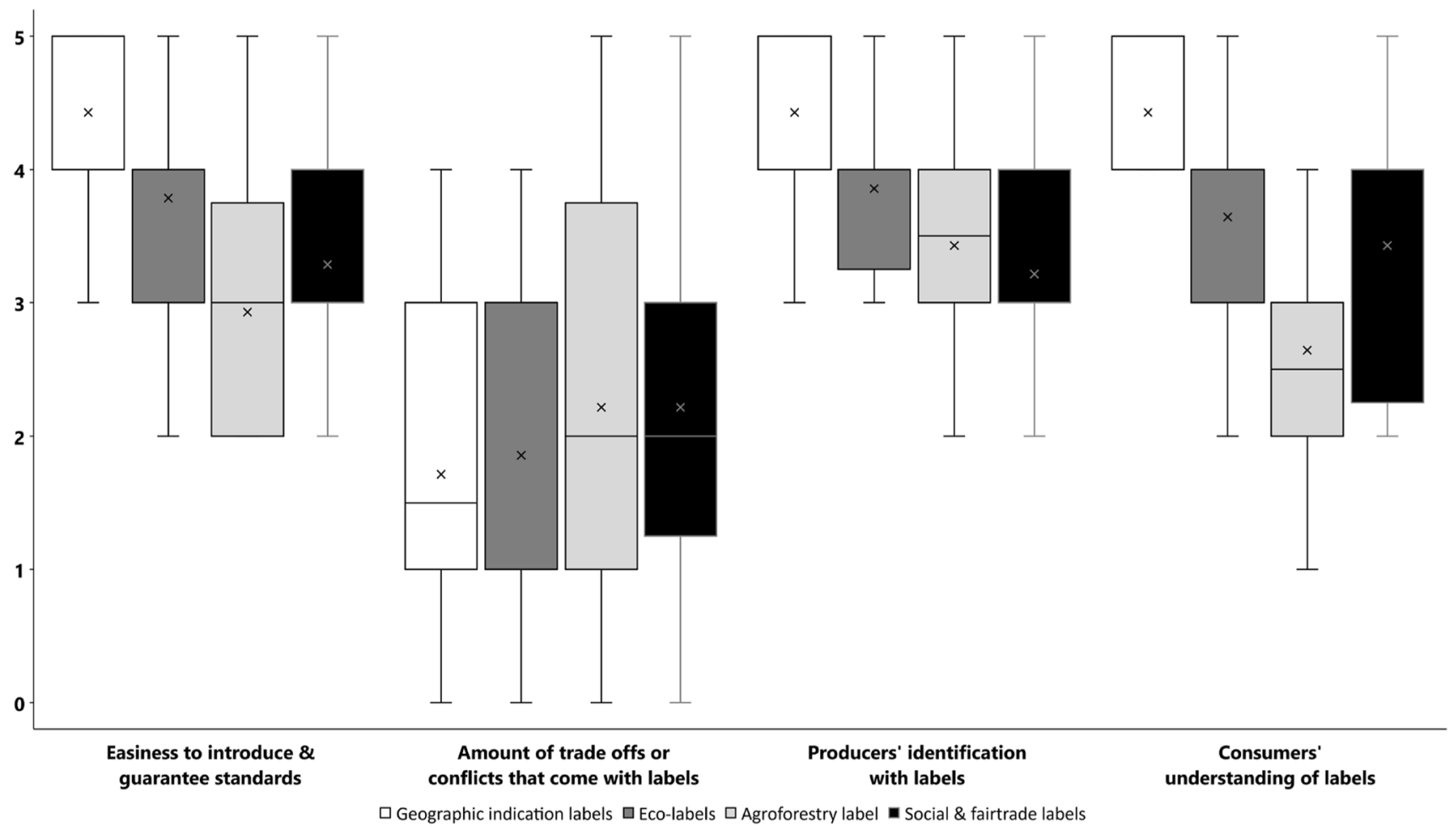

Fig. 2 Assessment of four different labelling options (differently coloured boxes) in relation to four potentials/issues (groups of boxes). The numbers result from a 5-point Likert scale rating, where the box

as ecosystem services and social-ecological systems (both 4.33) following close.

In Round 3, we asked the participants to rate five potentials barriers that keep farmers or land managers from joining labelling schemes, offering the options of "not a barrier" itself displays second and third quartiles; the inner line shows the mean value and the whiskers display the full data range

(0), "maybe a barrier" (1) and "surely a barrier" (2). Here, the biggest barriers appeared to be the initial costs of certification with a rating of 1.71 (out of 2 ) and the time requirement for farmers (1.64). The necessary compliance with rules and the problem of finding no final market (both at 
1.50) were also considered relevant barriers while missing economic benefits, with a rating of 1.21 , were not. Additional barriers, both mentioned twice by the participants, were the long-term fees for certification schemes that might not pay off, as well as policy issues-either as a lack of supporting policies or as existing policies that prevent farmers from making certain management decisions on their own.

In Round 3, we also asked the respondents how they would bridge the gap for indicators, where the practical applicability was rated high, but the consumers' understanding was low or vice versa. The answers showed slightly higher importance for educating consumers $(n=12)$ than for training producers $(n=9)$. The respondents consensually suggested promotion campaigns for the first and better producer education for the second issue. To avoid $(n=7)$ or improve $(n=8)$ problematic indicators was also selected by more than half of the respondents, but received fewer comments on how to tackle the issue. At the end of round 3, we asked them to assess three potential issues of agroforestry labelling and the positive potential which they see regarding future labelling efforts in agroforestry production systems. The respondents stated a high potential for future labelling efforts (3.71 Likert points) but also claimed strong concerns with regard to competing labels (3.57 points). Greenwashing (2.21 points) and market saturation for labelled products (at 2.00 points) were not assessed as potentially relevant issues.

\section{Discussion}

\section{Relating agroforestry to sustainability}

The responding experts rated 12 sustainability aspects to be relevant for capturing sustainability in agroforestry systems, with the highest scores pointing to aspects of sustainable resource consumption (SDG 12), climate-smart agriculture (SDG 13), diversification and innovation (SDG 8), income and social coherence (SDG 1), quality of life (SDG 3), and biodiversity (SDG 15). Still, during the first step of our survey, five SDGs dropped out due to low rankings: respondents did not see direct links of agroforestry systems with gender equality (SDG 5), clean energy (SDG 7), sustainable cities (SDG 11), and life below water (SDG 14). At the same, the low rating of zero hunger (SDG 2) was surprising as most agroforestry systems are food systems. A possible explanation could be the low perceived importance of agroforestry systems for food production compared to large-scale monoculture systems, although studies show that agroforestry systems can achieve higher yields per area (Waldron et al. 2017; van Noordwijk et al. 2018). A second reason can be that the participating experts mainly focus on the European Mediterranean area where hunger and nutritional safety are considered less relevant issues than for example within the
African context (Mbow et al. 2014). Furthermore, having labelling already in mind, it has to be acknowledged that, for some aspects, the sustainability of practices can only be indicated at farm level. By contrast, other sustainability aspects, such as gender distribution, food security, or sustainable cities, have to be assessed (and regulated) on larger scales. In this regard, Geographic Indications perform differently as they work on a precisely defined landscape scale, at the same making them less sensitive for farm-scale issues.

We find a good overlapping when comparing our results with the SDGs that the FAO Report on Mediterranean Forests (FAO and Plan Bleu 2018) suggests as relevant. Six of the SDGs that we identified as relevant also been mentioned as important by FAO, but we especially miss innovation and infrastructure (SDG 9) and responsible consumption and production (SDG 12) in their list. Furthermore, according to the experts' rating, a label using cultural heritage and traditional landscapes for marketing would represent innovation and infrastructure (SDG 9) well. With our survey, we could show that agroforestry is not only theoretically connected to certain SDGs, but experts confirm their relevance in terms of labelling. Given, that we had more than $50 \%$ overlapping between the SDG-based aspects and the experts' free listing, our list of 12 sustainability aspects seems robust for representing the relevant SDGs.

\section{Assessing indicator suitability}

Based on the classification of the indicators (Table 3), we recommend 11 of them as generally applicable. In addition, we propose four of them as "umbrella indicators" that are, according to our results, easy to apply, easy to understand, and can represent the key sustainability characteristics of a sustainable agroforestry landscape management. Salaries of farmworkers can represent social-economic well-being, livelihood, and education. The avoidance of chemical fertilisers and pesticides supports not only the integrity of ecosystems and water bodies but also a sustainable use of resources. The use of cultural traditions and landscapes for marketing is useful for labels that emphasise terroir and regionality of production. Finally, areas that are set aside for conservation can be an indicator of the various ecological aspects of sustainability. Coinciding with our findings, the report of FAO and Plan Bleu (2018) mention SDGs related to three of those four umbrella indicators as important for Mediterranean forestry, with clean water and conservation being highlighted as the most relevant ones.

By developing the indicators based on the SDGs, we claim to cover a broader range of sustainability aspects compared to other agroforestry-specific studies. Detailed work on agricultural indicators mostly focuses on productive values and splitting indicators by the three pillars of sustainability (Escribano et al. 2018). Other studies such as Nair 
and Toth (2016) focus more on the broad concept of sustainability, but at the same time stress the priority of ecological sustainability. Besides defining and refining ever more indicators, the "Local Governments for Sustainability" network (ICLEI) suggests limiting the number of indicators and the use of multifunctional indicators (Woodbridge 2015). We claim that some umbrella indicators can reflect sustainability in a wide sense, cover more than one SDG at the same time, act as a proxy value for several targets, and transfer sustainability goals to a landscape scale (Millard 2011). To not separate sustainability aspects by three sustainability pillars seems conceptually helpful when developing umbrella indicators. For sure, there are more indicators than we assessed in our survey, which could be used as umbrella indicators, as well.

\section{Barriers and potentials for agroforestry labelling}

Besides stating a large potential for labelling agroforestry products, the experts highlighted initial and ongoing costs for certification as well as the extra time required for certification efforts as major barriers, which keep farmers from joining labelling schemes. Regarding the consumer side, one expert stated that "consumers are not yet aware of all benefits of agroforestry, especially all ecosystem services provided, and do not know the term either", but the experts agreed that this could be improved by clear explanations (e.g., "clarity is needed everywhere, even more in this case with all this confusion of what is agroforestry"). They proposed to improve the understanding of labels, e.g., by educating consumers about the complexity and multifunctionality of agroforestry systems, by inventing agroforestry-specific indicators, or by developing a label specifically for agroforestry. The latter is a widespread idea within the agroforestry community, for example, supported by the European Agroforestry Federation (Borremans 2019). A final free text evaluation on the potential future of agroforestry labelling revealed a central conflict between two main issues. On one hand, experts agreed that the certification itself could support various dimensions of sustainability and climate protection, if properly communicated to consumers. On the other hand, many experts pointed to the risk of a vague unique selling point of a possible label, as the term agroforestry covers a wide range of practices and landscape characteristics. Furthermore, a growing interest in agroforestry products could offer economic opportunities but also threaten intact forests when land is not taken from degraded areas (Plieninger and Gaertner 2011; Millard 2011). Thus, instead of developing a label specifically for agroforestry systems, several experts pointed out the potential of existing labels, such as Geographic Indications.

Four experts highlighted the potential of Geographic Indications, with one of them stating: "A Geographical
Agroforestry system that is built on the established framework of Geographic Indications and incorporates agroforestry practices" and three more respondents suggested to use Geographic Indications or terroir characteristics for labelling in agroforestry systems. In our study, Geographic Indications were suggested for their unique potential to support cultural heritage and access to financing, which originated from relatively low-ranked sustainability aspects (Table 3). Despite not explicitly being developed for sustainability, Geographic Indications guarantee the traditional production standards and protect local specialities (Clark and Kerr 2017; Bérard and Marchenay 2006). They use the term 'terroir' to refer to product characteristics linked to a specific geographic area and landscape management. Especially for coffee and cocoa systems, studies have already shown that Geographic Indications can transmit values of sustainable landscape management to markets and consumers (Marie-Vivien et al. 2014) and also protect intellectual properties regarding place-based traditional processing techniques (Quiñones-Ruiz et al. 2015). More generally can be said that food systems are strongly interconnected with regional social-ecological characteristics and, therefore, highly relevant for the corresponding landscape (Penker and Wytrzens 2005) and its various values (Raymond et al. 2016). Not mentioned within the survey but in related literature, landscape labelling could be another starting point for developing an agroforestry label as this includes geographic characteristics as well as product specifications (Ghazoul et al. 2009; Ghazoul 2013).

The positive impacts of agroforestry practices on ecosystem services at a landscape level have been widely demonstrated. (Torrralba et al. 2016). However, the connections between agroforestry landscapes, Geographic Indications, and the SDG agenda have not been investigated in detail (Gauquelin et al. 2018; Millard 2011). For example, the economic benefits of Geographic Indications were documented by FAO (Vandecandelaere et al. 2018), but the benefits for maintaining traditional, valuable landscapes, and practices remain unclear and should be part of further investigation. Therefore, the proposal of an agroforestry label based on terroir characteristics may express that in the social-cultural context of agroforestry landscapes, sustainability can be represented quite well through Geographic Indications. Within the current system of Geographic Indications, the strong focus on high-quality specialities and the need for a coherent local interest group limit the expansion of this approach to basic staple food products.

\section{Limitations}

The Delphi method is an approach that builds on experts' knowledge and that is often characterised by small sample sizes and potential bias in the selection of study participants. Despite our efforts to include a large and broad suite 
of experts, the number of respondents was limited. We found that the more engaged respondents stayed until the end, as demonstrated by the fact that there were no experts leaving questions open during the last two rounds. Declining numbers of participants for each survey round (starting with 23 , ending with 13 respondents) and connecting to participants with diverse professional backgrounds were problematic. Although we addressed people with different professional status working in agroforestry or within the labelling sector, almost exclusively experts from universities or with academic background joined our study. Therefore, we cannot claim comprehensive stakeholder participation for this survey; rather, we carried out an explorative scoping based on experts' knowledge. Still, we agree with Escribano et al. (2018) that the Delphi method can synthesise expert knowledge to assess indicators and labelling approaches according to their relevance and practicability.

The necessary time to answer the questionnaires and the long lists of up to 17 items were key reasons for the declining participation rate of experts. At the same time, a clear structure and the use of rankings (instead of ratings) were used to avoid misunderstanding and missing responses. Furthermore, all numbers presented (rankings, Likert points and arithmetic means of both) are not denoted as statistically significant results due to the small and less diverse sample. We treat the rankings, ratings, and free listing answers as part of a scoping that helps to understand the current issues and potentials for labelling agroforestry products.

\section{Conclusion}

Mediterranean landscapes host a variety of different agroforestry systems. Many of these extensively managed systems like dehesas in Spain or montados in Portugal are challenged by diminishing economic revenues. Labels have the potential to promote sustainable agroforestry management and thus raise market awareness but also advocate for the conservational value that these types of traditional landscape management deliver to society. Therefore, agroforestry systems need different indicators compared to conventional agriculture. We found 11 indicators that were rated as useful to be assessed in the agroforestry context. For business-based certification schemes, indicators should be comprehensible for consumers and easy to monitor. For scientific or administrative monitoring, more complex indicators can be considered. Meanwhile, for marketing reasons, we suggest the development of agroforestry-specific umbrella indicators that reflect the sustainable management of agroforestry landscapes in a more comprehensive way, regarding the socio-economic well-being and the integrity of social-ecological systems. Smartly designed indicators for income, rural livelihoods, and traditions as well as protection of natural resources can act as proxies for overall sustainability. Accordingly, further research is needed to develop indicators tailored to agroforestry labels. To assure sustainability on higher scales and to provide context-specific or complex monitoring data, the performance of labelling strategies has to be assessed in combination with governmental regulation and other related governance systems, among which labelling is only one instrument in the sustainability toolbox.

For labelling agroforestry products, we suggest to include elements of distinct regional and geographical characteristics, such as terroir, traditional management practices, traditional processing, and place-based social-cultural values, to make up for the badly known term 'agroforestry'. The potential to make use of those geographical characteristics in relation to agroforestry systems is currently underestimated or at least not systematically used. Here, we see the need to investigate the interlinkage and joint application of existing labels of geographical origin, agroforestry, and the support for social-ecological sustainability.

Acknowledgements Open Access funding provided by Projekt DEAL. We are grateful to 23 participants that took part in the Delphi survey, to our colleagues at the Universities of Göttingen and Kassel for pretesting and offering feedback and to the anonymous reviewers for their helpful comments. This research has been funded by the Deutsche Forschungsgemeinschaft (DFG, German Research Foundation)—project number 426675955 and contributes to the Programme on Ecosystem Change and Society (https://pecs-science.org/) and the Global Land Programme (www.glp.earth).

Open Access This article is licensed under a Creative Commons Attribution 4.0 International License, which permits use, sharing, adaptation, distribution and reproduction in any medium or format, as long as you give appropriate credit to the original author(s) and the source, provide a link to the Creative Commons licence, and indicate if changes were made. The images or other third party material in this article are included in the article's Creative Commons licence, unless indicated otherwise in a credit line to the material. If material is not included in the article's Creative Commons licence and your intended use is not permitted by statutory regulation or exceeds the permitted use, you will need to obtain permission directly from the copyright holder. To view a copy of this licence, visit http://creativecommons.org/licenses/by/4.0/.

\section{References}

Aertsens J, de Nocker L, Gobin A (2013) Valuing the carbon sequestration potential for European agriculture. Land Use Policy 31:584594. https://doi.org/10.1016/j.landusepol.2012.09.003

Aronson J, Pereira JS, Pausas JG (eds) (2009) Cork oak woodlands on the edge. Ecology, adaptive management, and restoration. Island Press, Washington

Bérard L, Marchenay P (2006) Local products and geographical indications: taking account of local knowledge and 
biodiversity. Int Soc Sci J 58(187):109-116. https://doi.org/10.1 111/j.1468-2451.2006.00592.x

Borremans L (2019) The development of agroforestry systems in Flanders. A farming systems research approach to social, institutional and economic inquiry. PhD Thesis, University of Brussels

Bugalho MN, Caldeira MC, Pereira JS, Aronson J, Pausas JG (2011) Mediterranean cork oak savannas require human use to sustain biodiversity and ecosystem services. Front Ecol Environ 9(5):278-286. https://doi.org/10.1890/100084

Camilli F, Pisanelli A, Seddaiu G, Franca A, Bondesan V, Rosati A, Moreno GM, Pantera A, Hermansen JE, Burgess PJ (2018) How local stakeholders perceive agroforestry systems: an Italian perspective. Agroforest Syst 92(4):849-862. https://doi.org/10.1007/ s10457-017-0127-0

Campos P, Oviedo JL, Álvarez A, Mesa B, Caparrós A (2019) The role of non-commercial intermediate services in the valuations of ecosystem services: application to cork oak farms in Andalusia. Spain Ecosyst Serv 39:100996. https://doi.org/10.1016/j.ecose r.2019.100996

Clark LF, Kerr WA (2017) Climate change and terroir: The challenge of adapting geographical indications. J World Intellect Prop 20(34):88-102. https://doi.org/10.1111/jwip.12078

Costa A, Madeira M, Lima Santos J, Oliveira Â (2011) Change and dynamics in Mediterranean evergreen oak woodlands landscapes of Southwestern Iberian Peninsula. Landsc Urban Plan 102(3):164-176. https://doi.org/10.1016/j.landurbpla n.2011.04.002

Costa A, Madeira M, Lima Santos J, Plieninger T (2014) Recent dynamics of evergreen oak wood-pastures in south-western Iberia. In: Hartel T, Plieninger T (eds) European wood-pastures in transition. A social-ecological approach. Taylor and Francis, Hoboken, pp 70-89

Dias FS, Bugalho MN, Rodríguez-González PM, Albuquerque A, Cerdeira JO (2015) Effects of forest certification on the ecological condition of Mediterranean streams. J Appl Ecol 52(1):190-198. https://doi.org/10.1111/1365-2664.12358

den Herder M, Moreno G, Mosquera-Losada RM, Palma JHN, Sidiropoulou A, Santiago Freijanes JJ, Crous-Duran J, Paulo JA, Tomé M, Pantera A, Papanastasis VP, Mantzanas K, Pachana P, Papadopoulos A, Plieninger T, Burgess PJ (2017) Current extent and stratification of agroforestry in the European Union. Agr Ecosyst Environ 241:121-132. https://doi.org/10.1016/j.agee.2017.03.005

Egea P, Pérez y Pérez L (2016) Sustainability and multifunctionality of protected designations of origin of olive oil in Spain. Land Use Policy 58:264-275. https://doi.org/10.1016/j.landusepol .2016.07.017

Elevitch C, Mazaroli D, Ragone D (2018) Agroforestry standards for regenerative agriculture. Sustainability 10(9):3337. https://doi. org/10.3390/su10093337

Escribano M, Díaz-Caro C, Mesias FJ (2018) A participative approach to develop sustainability indicators for dehesa agroforestry farms. Sci Total Environ 640-641:89-97. https://doi.org/10.1016/j.scito tenv.2018.05.297

FAO and Plan Bleu (2018) State of mediterranean forests 2018. Marseille

Gauquelin T, Michon G, Joffre R, Duponnois R, Génin D, Fady B, Bou Dagher-Kharrat M, Derridj A, Slimani S, Badri W, Alifriqui M, Auclair L, Simenel R, Aderghal M, Baudoin E, Galiana A, Prin Y, Sanguin H, Fernandez C, Baldy V (2018) Mediterranean forests, land use and climate change: a social-ecological perspective. Reg Environ Change 18(3):623-636. https://doi.org/10.1007/ s10113-016-0994-3

Ghazoul J (2013) Landscape labeling: combining certification with ecosystem service conservation at landscape scales. In: Koellner
$\mathrm{T}$ (ed) Ecosystem services and global trade of natural resources. Routledge, Abingdon, pp 242-261

Ghazoul J, Garcia C, Kushalappa CG (2009) Landscape labelling: a concept for next-generation payment for ecosystem service schemes. For Ecol Manage 258(9):1889-1895. https://doi. org/10.1016/j.foreco.2009.01.038

Hartel T, Plieninger T (eds) (2014) European wood-pastures in transition. A social-ecological approach. Taylor and Francis, Hoboken

Hasson F, Keeney S, McKenna H (2000) Research guidelines for the Delphi survey technique. J Adv Nurs 32(4):1008-1015

Hertel TW (2015) The challenges of sustainably feeding a growing planet. Food Sec 7(2):185-198. https://doi.org/10.1007/s1257 1-015-0440-2

Herzog F (1998) Streuobst: a traditional agroforestry system as a model for agroforestry development in temperate Europe. Agroforest Syst 42(1):61-80. https://doi.org/10.1023/A:1006152127824

Horrillo A, Escribano M, Mesias FJ, Elghannam A, Gaspar P (2016) Is there a future for organic production in high ecological value ecosystems? Agric Syst 143:114-125. https://doi.org/10.1016/j. agsy.2015.12.015

Huntsinger L, Oviedo JL (2014) Ecosystem services are social-ecological services in a traditional pastoral system: the case of California's Mediterranean rangelands. Ecol Soc 19(1):8. https://doi. org/10.5751/ES-06143-190108

Jose S (2009) Agroforestry for ecosystem services and environmental benefits: an overview. Agroforest Syst 76(1):1-10. https://doi. org/10.1007/s10457-009-9229-7

Kanter DR, Musumba M, Wood SLR, Palm C, Antle J, Balvanera P, Dale VH, Havlik P, Kline KL, Scholes RJ, Thornton P, Tittonell P, Andelman S (2018) Evaluating agricultural trade-offs in the age of sustainable development. Agric Syst 163:73-88. https:// doi.org/10.1016/j.agsy.2016.09.010

Lin BB (2011) Resilience in agriculture through crop diversification: adaptive management for environmental change. Bioscience 61(3):183-193. https://doi.org/10.1525/bio.2011.61.3.4

Lorenz K, Lal R (2014) Soil organic carbon sequestration in agroforestry systems. A review. Agron Sustain Dev 34(2):443-454. https ://doi.org/10.1007/s13593-014-0212-y

Lovrić M, Rois-Díaz M, den Herder M, Pisanelli A, Lovrić N, Burgess PJ (2018) Driving forces for agroforestry uptake in Mediterranean Europe: application of the analytic network process. Agroforest Syst 92(4):863-876. https://doi.org/10.1007/s10457-018-0202-1

Malek Ž, Verburg P (2017) Mediterranean land systems: representing diversity and intensity of complex land systems in a dynamic region. Landsc Urban Plan 165:102-116. https://doi. org/10.1016/j.landurbplan.2017.05.012

Malek Ž, Verburg PH, Geijzendorffer RI, Bondeau A, Cramer W (2018) Global change effects on land management in the Mediterranean region. Global Environ Change 50:238-254. https://doi. org/10.1016/j.gloenvcha.2018.04.007

Mann C, Plieninger T (2017) The potential of landscape labelling approaches for integrated landscape management in Europe. Landsc Res 42(8):904-920. https://doi.org/10.1080/01426 397.2017.1335863

Mann C, Garcia-Martin M, Raymond CM, Shaw BJ, Plieninger T (2018) The potential for integrated landscape management to fulfil Europe's commitments to the Sustainable Development Goals. Landsc Urban Plan 177:75-82. https://doi.org/10.1016/j.landu rbplan.2018.04.017

Marie-Vivien D, Garcia CA, Kushalappa CG, Vaast P (2014) Trademarks, geographical indications and environmental labelling to promote biodiversity: the case of agroforestry coffee in India. Dev Policy Rev 32(32):379-398 
Masiero M, Amariei L, Secco L, Leonardi A, Marchetti M (2011) FSCcertified non timber forest products and forest services: is there an evidence of marketing advantages? Viterbo

Mbow C, van Noordwijk M, Prabhu R, Simons T (2014) Knowledge gaps and research needs concerning agroforestry's contribution to Sustainable Development Goals in Africa. Curr Opin Environ Sustain 6:162-170. https://doi.org/10.1016/j.cosust.2013.11.030

Millard E (2011) Incorporating agroforestry approaches into commodity value chains. Environ Manage 48(2):365-377. https:// doi.org/10.1007/s00267-011-9685-5

Montagnini F (2017) Integrating landscapes: agroforestry for biodiversity conservation and food sovereignty. Advances in Agroforestry, vol 12. Springer International Publishing, Cham. https://doi. org/10.1007/978-3-319-69371-2

Moreno G, Aviron S, Berg S, Crous-Duran J, Franca A, de Jalón SG, Hartel T, Mirck J, Pantera A, Palma JHN, Paulo JA, Re GA, Sanna F, Thenail C, Varga A, Viaud V, Burgess PJ (2018) Agroforestry systems of high nature and cultural value in Europe: provision of commercial goods and other ecosystem services. Agroforest Syst 92(4):877-891. https://doi.org/10.1007/s10457-017-0126-1

Mosquera-Losada MR, Moreno G, Pardini A, McAdam JH, Papanastasis V, Burgess PJ, Lamersdorf N, Castro M, Liagre F, RigueiroRodríguez A (2012) Past, present and future of agroforestry systems in Europe. In: Nair PR, Garrity D (eds) Agroforestry-the future of global land use, vol. 9. Springer, Dordrecht, pp 285-312. https://doi.org/10.1007/978-94-007-4676-3_16

Mosquera-Losada MR, Santiago-Freijanes JJ, Rois-Díaz M, Moreno G, den Herder M, Aldrey-Vázquez JA, Ferreiro-Domínguez N, Pantera A, Pisanelli A, Rigueiro-Rodríguez A (2018) Agroforestry in Europe: a land management policy tool to combat climate change. Land Use Policy 78:603-613. https://doi.org/10.1016/j. landusepol.2018.06.052

Mukherjee N, Hugé J, Sutherland WJ, McNeill J, van Opstal M, Dahdouh-Guebas F, Koedam N (2015) The Delphi technique in ecology and biological conservation: applications and guidelines. Methods Ecol Evol 6(9):1097-1109. https://doi. org/10.1111/2041-210X.12387

Mukherjee N, Zabala A, Huge J, Nyumba TO, Adem Esmail B, Sutherland WJ (2018) Comparison of techniques for eliciting views and judgements in decision-making. Methods Ecol Evol 9(1):54-63. https://doi.org/10.1111/2041-210X.12940

Nair PKR, Toth GG (2016) Measuring agricultural sustainability in agroforestry systems. In: Lal R, Kraybill D, Hansen DO, Singh BR, Mosogoya T, Eik LO (eds) Climate change and multi-dimensional sustainability in African agriculture vol 18. Springer International Publishing, Cham, pp 365-394

OECD (2016) Environmental labelling and information schemes. Policy Perspectives, Paris

Pe'er G, Lakner S, Müller R, Passoni G, Bontzorlos V, Clough D, Moreira F, Azam C, Berger J, Bezak P, Bonn A, Hansjürgens B, Hartmann L, Kleemann J, Lomba A, Sahrbacher A, Schindler S, Schleyer C, Schmidt J, Schüler S, Sirami C, Meyer-Höfer M von, Zinngrebe Y (2017) Is the CAP fit for purpose? An evidencebased fitness check assessment. Leipzig

Pe'er G, Zinngrebe Y, Moreira F, Sirami C, Schindler S, Müller R, Bontzorlos V, Clough D, Bezák P, Bonn A, Hansjürgens B, Lomba A, Möckel S, Passoni G, Schleyer C, Schmidt J, Lakner S (2019) A greener path for the EU Common Agricultural Policy. Science 365(6452):449-451. https://doi.org/10.1126/science.aax3146

Penker M, Wytrzens HK (2005) Scenarios for the Austrian food chain in 2020 and its landscape impacts. Landsc Urban Plan 71(24):175-189. https://doi.org/10.1016/j.landurbplan.2004.03.002

Pisanelli A, Marandola D, Marongiu S, Paris P, Rosati A, Romano $R$ (2014) The role of rural development policy in supporting agroforestry. In: Palmac JHN (ed) 2nd European agroforestry conference. Book of abstracts. Integrating Science and Policy to Promote Agroforestry Practice, Cottbus, pp 22-25

Plieninger T, Gaertner M (2011) Harnessing degraded lands for biodiversity conservation. J Nat Conserv 19(1):18-23. https://doi. org/10.1016/j.jnc.2010.04.001

Plieninger T, Huntsinger L (2018) Complex rangeland systems: integrated social-ecological approaches to silvopastoralism. Rangel Ecol Manag 71(5):519-525.https://doi.org/10.1016/j. rama.2018.05.002

Pollastrini M, Chiavetta U, Cutini A, Casula A, Maltoni S, Dettori S, Corona P (2018) Indicators for the assessment and certification of cork oak management sustainability in Italy. iForest 11(5):668 674. https://doi.org/10.3832/ifor2587-011

Quiñones-Ruiz XF, Penker M, Vogl CR, Samper-Gartner LF (2015) Can origin labels re-shape relationships along international supply chains?-The case of Café de Colombia. Inte J Commons 9(1):416-439

Raymond CM, Bieling C, Fagerholm N, Martin-Lopez B, Plieninger $\mathrm{T}$ (2016) The farmer as a landscape steward: comparing local understandings of landscape stewardship, landscape values, and land management actions. Ambio 45(2):173-184. https://doi. org/10.1007/s13280-015-0694-0

Santiago-Freijanes JJ, Mosquera-Losada MR, Rois-Díaz M, FerreiroDomínguez N, Pantera A, Aldrey JA, Rigueiro-Rodríguez A (2018a) Global and European policies to foster agricultural sustainability: agroforestry. Agroforest Syst 31(1):584. https://doi. org/10.1007/s10457-018-0215-9

Santiago-Freijanes JJ, Pisanelli A, Rois-Díaz M, Aldrey-Vázquez JA, Rigueiro-Rodríguez A, Pantera A, Vityi A, Lojka B, FerreiroDomínguez N, Mosquera-Losada MR (2018b) Agroforestry development in Europe: policy issues. Land Use Policy 76:144-156. https://doi.org/10.1016/j.landusepol.2018.03.014

Torralba M, Fagerholm N, Burgess PJ, Moreno G, Plieninger T (2016) Do European agroforestry systems enhance biodiversity and ecosystem services? A meta-analysis. Agr Ecosyst Environ 230:150 161. https://doi.org/10.1016/j.agee.2016.06.002

Torralba M, Fagerholm N, Hartel T, Moreno G, Plieninger T (2018a) A social-ecological analysis of ecosystem services supply and tradeoffs in European wood-pastures. Sci Adv 4(5):eaar2176. https:// doi.org/10.1126/sciadv.aar2176

Torralba M, Oteros-Rozas E, Moreno G, Plieninger T (2018b) Exploring the role of management in the coproduction of ecosystem services from Spanish wooded rangelands. Rangel Ecol Manag 71(5):549-559. https://doi.org/10.1016/j.rama.2017.09.001

Tscharntke T, Milder JC, Schroth G, Clough Y, DeClerck F, Waldron A, Rice R, Ghazoul J (2015) Conserving biodiversity through certification of tropical agroforestry crops at local and landscape scales. Conserv Lett 8(1):14-23. https://doi.org/10.1111/ conl. 12110

van Noordwijk M, Duguma LA, Dewi S, Leimona B, Catacutan DC, Lusiana B, Öborn I, Hairiah K, Minang PA (2018) SDG synergy between agriculture and forestry in the food, energy, water and income nexus: reinventing agroforestry? Curr Opin Environ Sustain 34:33-42. https://doi.org/10.1016/j.cosust.2018.09.003

van Oudenhoven APE, Schröter M, Drakou EG, Geijzendorffer IR, Jacobs S, van Bodegom PM, Chazee L, Czúcz B, Grunewald K, Lillebø AI, Mononen L, Nogueira AJA, Pacheco-Romero M, Perennou C, Remme RP, Rova S, Syrbe R-U, Tratalos JA, Vallejos M, Albert C (2018) Key criteria for developing ecosystem service indicators to inform decision making. Ecol Ind 95:417-426. https ://doi.org/10.1016/j.ecolind.2018.06.020

Vandecandelaere E, Teyssier C, Barjolle D, Jeanneaux P, Fournier S, Beucherie O (2018) Strengthening sustainable food systems through geographical indications. An analysis of economic impacts. Directions in investment. Report, no. 13. FAO. Rome 
Waldron A, Garrity D, Malhi Y, Girardin C, Miller DC, Seddon N (2017) Agroforestry can enhance food security while meeting other sustainable development goals. Trop Conserv Sci 10:1-6. https://doi.org/10.1177/1940082917720667

Wolpert F, Quintas-Soriano C, Plieninger T (2020) Exploring land-use histories of tree-crop landscapes: a cross-site comparison in the Mediterranean Basin. Sustainability Science (accepted)

Woodbridge M (2015) Measuring, monitoring and evaluating the SDGs. ICLEI Briefing Sheet No. 06. Bonn. https://www.local
2030.org/library/236/ICLEI-SDGs-Briefing-Sheets-06-Measu ring-Monitoring-and-Evaluating-the-SDGs.pdf

Publisher's Note Springer Nature remains neutral with regard to jurisdictional claims in published maps and institutional affiliations. 